\section{LOCAL AUTHORITIES' POLICIES \\ FOR DISSEMINATING GENDER EQUALITY. EVIDENCE FROM ITALY}

\section{Elena GORI}

Alberto ROMOLINI

\section{Silvia FISSI}

\author{
Elena GORI \\ Associate professor, Ph.D., Department of Business \\ and Economics, University of Florence, Florence, Italy \\ Tel.: 0039-055-275.9711 \\ E-mail: elena.gori@unifi.it
}

\author{
Alberto ROMOLINI (Corresponding author) \\ Associate professor, Ph.D., Faculty of Economics, \\ International Telematic University UNINETTUNO, Rome, Italy \\ Tel.: 0039-066-920.7640/50 \\ E-mail: a.romolini@uninettunouniversity.net
}

\section{Silvia FISSI}

Assistant professor, Ph.D., Department of Business and Economics, University of Florence, Florence, Italy

Tel.: 0039-055-275971

E-mail: silvia.fissi@unifi.it

\section{Abstract}

This paper aims to analyze the role of Italian local authorities in disseminating gender equality by using the gender mainstreaming approach. Previous researches in gender were concentrated on legal aspect linked to labor or to violence against women. Moreover, other studies examined the effects of EU funds on local gender policies. However, no research results are provided about methodologies, timing and responsibilities set up by local administrations.

The research focuses on a population consisting of local authorities representing the principal regional towns and analyzes the Italian local authorities' commitment in gender mainstreaming. The result of the analysis is that the local authorities are demonstrating more commitment with policies linked to employment issues. Moreover, Italian municipalities show a significant commitment to spreading GM policies, not only dedicated to women but also to a more inclusive concept of 'gender'. However, we argue that policies for gender equality are not target-driven: local authorities widespread a wide range of gender policies without defining an adequate tool. Policy makers need to reflect about the possibility to develop a clear frame concerning strategies, resources, measuring and impact indicators in order to issue real 'gender effective policies'.

Keywords: gender mainstreaming, local authorities, gender equality, public policy, Italy. 


\section{Introduction}

The European Institute for Gender Equality (EIGE), founded in 2010 in order to contribute and strengthen the promotion of gender equality, is an autonomous body of the EU (EIGE, 2015a). It aims to become the EU's knowledge center on gender equality by collecting information and by sharing useful experiences and expertise. Its activities are focused mainly on supporting gender mainstreaming in all EU and national policies in order to reduce gender discrimination.

Within the gender equality approach, the strategy and the tools used to promote it are known as 'gender mainstreaming' (EIGE, 2015b). For EU countries, the progress in the quest for gender equality is due mainly to the adoption of EU directives and to the use of EU funds dedicated to the gender mainstreaming approach. Gender mainstreaming has been embraced internationally as a strategy towards realizing gender equality. It involves the integration of a gender perspective into the preparation, design, implementation, monitoring and evaluation of policies, regulatory measures and spending programs, with a view to promoting equality between women and men, and combating discrimination.

While Europe has made step-by-step progress over recent years, thanks to hard work at local, national and European levels, gender equality still remains an unfinished business. We are far from reaching equality, particularly in areas such as participation in the labor market, economic independence, pay and pensions, equality in leadership positions, fighting gender-based violence and gender equality in our external action (EIGE, 2015c).

In 2013, the EIGE developed the Gender Equality Index as a unique tool that summarizes the complexity of gender equality into a user-friendly and easily interpretable measure (EIGE, 2015d). As it is based on the EU policy framework, its result has been designed for policymakers in the EU. The Gender Equality Index 2015 provides results for all member states and the EU as a whole, on domain and sub-domain levels. The index shows a slight advance in gender equality between 2005 and 2012: the score for the 28 member states rises from 51.2 in 2005 to 52.9 (out of 100) in 2012.

Italy is ranked amongst the EU countries with the lowest gender equality level: its performance is above the EU average in only one area, namely health, thanks to Italian women's long life-expectancy and it reaches a score of 41.1 in 2012 with significant differences within other domains (work, money, knowledge, time, power and health). Even according to the Global Gender Gap Report (2015), Italy is highlighted as lacking in gender equality: its global ranking is 41 out of 73 countries with many problems in economics participation and opportunity, and political empowerment. Moreover, in Italy, policies to re-address the gender imbalance have been cautious, while progress in the legal framework has been promoted mainly by directives emanating from the EU or by pressures of the civil society (Rosselli, 2014).

Even if much of the gender literature focuses on the private sector (Mastracci and Bowman, 2015), public-sector organizations are more likely to disseminate gender strategies for achieving gender equality (Riccucci, 2009). According to Connell and 
Messerschmidt (2005) and to Davies and Thomas (2002), gender equality is linked to new public management in public-sector organizations, which rejects old-style bureaucracy, based mainly on a concept of hegemonic masculinity, and it believes in smart organizations, equal opportunity and family-friendly policies.

Gender mainstreaming strategies must be pursued at all levels of public administration, especially at local level. Indeed, as the public institutions most accessible to citizens, local authorities have the responsibility to execute a mandate to satisfy their constituents' needs, mainly through the provision of basic services. According to Law no. 53/2000, Italian local authorities are responsible for life quality and have been pressed to conduct positive action to reduce gender inequality. Local authorities are the major actors for public needs and have to spread policies in order to guarantee gender equality issues (Pulejo, 2009).

This paper aims to analyze the Italian local authorities' policies in promoting gender equality by using the gender mainstreaming approach. In other words, the goal is to understand which gender strategies are engaging Italian local authorities in and what tools they are using to improve, and to test gender equality.

\section{Furthering gender equality through the gender mainstreaming approach}

Gender, in a wider interpretation, does not define merely the physical differences between men and women but also the distinction between people according to biological nature, such as cultural and social identity. Gender identity must be defined independently from sex and sexual orientation (Sellers, 2014). Çă̆atay (2003) highlights that gender has to be considered a 'social category', useful in understanding lifestyles, behavior models and expectancies.

Since the 1950s, several theories on gender, women and development have been presented (Pollack and Hafner-Burton, 2000). Within the most recent, inspired by the European Commission, we analyze the Gender and Development Approach (GAD) and within the GAD approach, Gender Mainstreaming (GM) (European Commission, 2010). Gender equality is the overarching and long-term development goal, while GM is a set of context-specific, strategic approaches as well as technical and institutional processes adopted to achieve that goal (United Nations, 2014a).

GM is a globally and pervasive accepted strategy for promoting gender equality (Walby, 2003). It has been established as a major international strategy for the promotion of gender equality in the Beijing Platform for Action (Moser and Moser, 2005; Pollack and Hafner-Burton, 2000). In 1995, the UN adopted the first resolution on GM to guide the implementation of global commitments on gender equality and the empowerment of women, and the EU adopted GM in 1997 with the Treaty of Amsterdam.

GM integrates gender equality components in public administrations, in central and local strategies and in services and sectorial programs. Mainstreaming is not an end in itself but a strategy, an approach, a means for public administrations to achieve the goal of gender equality (Pulejo, 2011a). In other words, it represents a deliberate 
and systematic notion for integrating a gender perspective into public policies and strategies.

Gender literature emerged in the 1970s, as a consequence of the feminist agenda, and it immediately pointed towards the inequities of male-dominated workplaces (Mastracci and Bowman, 2015) alongside gender stereotyping and the under-representation of women in their workplaces, professions and policy-making bodies (Lehman, 2012). Since the late 1980s, there has been an increasing interest in gender-related issues in managerial and economics literatures with researches about the presence of females on firms' boards of directors (Nielsen and Huse, 2010; Luckerath-Rovers, 2013) and about the benefits of women's work (Acker, 1992; Davies and Thomas, 2000). Other studies have focused on the wage gap between men and women (Kangasniemi and Kauhanen, 2013).

However, GM is a vague concept. Woodward (2008) states that GM has been defined in many different ways, so it has become a 'container concept' where every user can furnish it with its own meaning. Moreover, it is difficult to understand the public entity responsible for GM implementation: when gender perspective should be added to all strategies, then mainstreaming suddenly becomes everybody's business and nobody's business (Tiessen, 2007).

According to the difficulties for public administrations in disseminating gender strategies, previous researches highlighted an interesting aspect in gender mainstreaming: gender equality is found to belong to the area of 'low politics' as it is an issue that is not considered vital to the survival of a nation. In particular, David and Guerrina (2013) found that GM is more visible on paper than in EU's countries policies: The gender equality is an actual issue for policy makers, but not effectively implemented. Furthermore, Daly (2005) highlighted many criticisms in comparative analysis concerning GM, as well as the under-theorization of the conceptual notions of the term. Bendl and Schmidt (2013) pointed out the need to open new avenues for better understanding gender mainstreaming.

Concerning public administrations' strategies to improve gender equality, Pulejo (2011b) analyzed gender responsive budget initiatives. Results highlight that GM strategies have to be pursued within each level of public administration, especially at local level. Martini (2011) studied the spread of gender budgets analysis in Italy. The results highlight that local authorities are the main users of this tool within Italian public administrations.

Despite progress in the legal framework, Italy lacks a proper gender infrastructure at central level. Moreover, policies issued to re-address the gender imbalance have been cautious. According to previous research, Italy has never produced an effective strategy to favor the inclusion of women into the labor market, based on the integration of different policy areas. The situation is slightly better within local administrations, especially at municipal level, where many gender policy initiatives have been carried out, by investing EU funds. However, to our knowledge, no research results are provided concerning methodologies, timing and responsibilities set up by local administrations. 
Research Question 1: As previous research highlights difficulties in disseminating gender equality policies, which gender strategies are engaging Italian local authorities in?; and

Research Question 2: What tools are Italian local authorities using to improve and to measure gender equality strategies?

\section{The development of gender policies in Italy}

The principle of equal opportunity is grounded in the Italian Constitution (Articles $3,37,51)$. Italian women voted for the first time in 1946; however, for twenty years, very little was done to enforce the principle of gender equality enshrined by the Constitution. Women's position in Italian society has been deeply affected by socio-cultural changes since the beginning of the 1970s (Lombardo and Del Giorgio, 2013). By the end of the 1960s, the call for change had grown louder, supported by strong civil rights and women's movements. In 1970, Statutes 898/1970 introduced the divorce law and in 1975, Parliament issued the reform of family law (Law no. 151/1975), putting an end to the traditional hierarchical structure of the family, dominated by the man. The crisis of the women's movement in the 1980s caused a meaning pause in gender equality issues and for a decade, women remained virtually absent from the public and the political scene.

The situation changed in the 1990s and 2000s, thanks to progress in gender equality originating mainly from the need to adopt EU Directives and the use of European funds (Rosselli, 2014). GM's strategic goal was initially foreseen in 1997 by the Directive Prodi-Finocchiaro and reinforced two years later by the introduction of the first GM operational tool, Strategic Impact Assessment on Equal Opportunity, which was fully developed during the 2000-2006 planning period.

Italian public administrations developed gender strategy at different governance level. At national level, GM has been coordinated primarily by the Equal Opportunities Department within the Presidency of the Council of Ministers (under the Vice-Minister for Labor and Social Policies). It was established in 1996 and acts as an operational unit. The Equal Opportunities Department is responsible for gender policy in structural funds. It plans, coordinates and manages the complex framework set up at national and local levels to support equal opportunity policies. It is also responsible for disseminating and coordinating gender policies in Italy.

Moreover, several gender-equality structures with advisory and monitoring functions have been established both at national and local level (Rosselli, 2014). Local authorities have a central role in achieving gender equality: however, a recent research highlighted that while many legislative initiatives have been initiated, measures to ensure their implementation remain weak (Pulejo, 2011b).

While Italian legislation has made much progress in enshrining gender equality, Italy is still falling short of achieving satisfactory results. The current financial crisis and austerity policies threaten gender achievements in terms of equality and all legislation requires greater awareness of these issues in order to design future policies and strategies (European Commission, 2013). 


\section{Method}

The inductive method was used in this exploratory research. We start from the general assumption that a policy will always contain an implicit or explicit representation of a diagnosis (what is the problem?), connected to an implicit or explicit prognosis (solution/s), and a call for action (Verloo, 2005). Both diagnosis and prognosis give fundamental information about who is deemed to have the problem, who caused it, and who should solve it (Lombardo and Meyer, 2008). In other words, the policy has been proposed to solve a problem, and if we examine policies, we are going to also examine local authorities' problems and solutions in achieving gender equality.

The research focuses on a population consisting of local authorities representing the chief regional towns. Our population comprised 20 local authorities with more than 5,000 inhabitants, across Italy.

The research analyses principal regional Italian towns' commitment to GM and thus, equality, through the analysis of strategic documents, such as the 'Documento Unico di Programmazione' (DUP) and the 'Piano delle Azioni Positive' (PAP) with qualitative and quantitative measures, examining formal (frame and issues) and substantial (budget, tools, diagnosis and prognosis) aspects of GM. The above-mentioned documents cover a three-year period and are the main tools for strategic planning within Italian local authorities. Given their importance in planning and implementing local strategies, DUP and PAP are regarded as the main building blocks to understanding local strategies and consequently, to evaluate gender equality and GM issues.

In particular, while DUP gives information about the territory and resources allocated for each strategy, PAP highlights local critical issues and indicates the way to solve them. Both documents give an overview of the past and ongoing development strategies; moreover, they set out priorities by outlining concrete development programs, add timetables, budgets and, sometimes, measurement indicators (Galizzi and Siboni, 2016). We excluded a gender-responsive report, as it is a voluntary disclosure and not widely and systematically diffused in Italy: occasional gender reporting is not useful in evaluating local policies' impact on the territory (Budlender and Hewitt, 2003).

Content analysis has been used to analyze DUPs and PAPs and has been widely applied to analyze social concerns in accounting, such as gender issues (Guthrie and Abeysekera, 2006; Parker, 2005). To that end, the researched items were developed on the basis of three documents: Gender Equality in Public Administration (United Nations, 2014b), GM in Development Programming: Guidance Note (United Nations, 2014a) and Strategic Engagement for Gender Equality (EIGE, 2015c). Content analysis was manually developed, using Excel to record disclosure in a specific worksheet shaped on the above-mentioned items. To detect possible progress over time, in terms of formal and substantial aspects of the GM approach, the research compares two generations of policy documents (2013-2015 and 2016-2018) by looking for their inclusion of gender equality issues. So, the file has recorded the presence and the 
frequency of gender-highlighted issues by adopting the 'phrase' as a unit of analysis of the texts. In particular, we recorded ' 1 ' when the unit of analysis was found in the document ('yes') and ' 0 ' if it was not ('no'). To disclose the prognosis more succinctly, we divided the total points by giving 0.5 point if the issue was present, and 0.5 point if the prognosis was spread within a timetable. Data and information have been collected using the form reported in Table 1.

\section{Results}

Of the 20 principal regional towns, only 16 were found with full documentation (DUPs and PAPs). The paucity mainly concerns PAPs that have not been updated in 16 out of 20 municipalities. This was conducted by checking all the local authorities' official websites during October 2016 and November 2016. Despite the fact that DUP and PAP are mandatory documents, and Italian regulations require local authorities to publish them on their websites, as yet not all public administrations have done so.

Regarding gender issues, the municipalities' organization is similar: each local authority has a specific assessor dedicated to gender equality. Milan, Palermo, Turin and Trento have a diversity manager, while Cagliari, Potenza and Rome have a gender equality board to encourage the implementation of gender strategies.

Table 2 highlights the general research results. L'Aquila municipality has been excluded from our research, as it has been deeply affected by the 2009 earthquake: the efforts and issues highlighted by its mandatory documents are mainly directed to the rebuilding of the city.

The results show an improvement in gender policies from 2013/2015 to 2016/2018: gender strategies points increased from 71 to 82; the presence of indicators from 2 to 7; the presence of a diagnosis from 40 to 47; and the presence of prognosis from 26.5 to 32 . The level of gender strategies wide-spreading is weak and remains low without any improvement, at 5 points. Summarizing, each municipality shows an increasing trend in formal and substantial aspects, as the performance of the triennium 2016/2018 is better than that of 2013/2015, with the exception of Campobasso, Florence, Milan and Rome.

An initial examination of results shows more attention on formal aspects in comparison to substantial ones: local authorities put more effort in drawing strategies, but the critical issue is that they do not insert them in a specific and objective picture. The risk is that the gender policies remain a 'declaration of intent' without any effective results, as municipalities do not use the tools to control the strategies' implementation, such as indicators and prognosis to solve gender problems. Moreover, local authorities show a low level in defining diagnoses of gender inequalities. This negative aspect affects gender policies.

Table 3 highlights our research's ranking of municipalities from 2013 to 2018. Bologna holds the first place and reaches the maximum score for both the definition of strategies and for the identification of the diagnosis. This means that there is a close link between identifying a diagnosis and individuating strategies to solve gen- 
Table 1: The form used to collect data and information

\begin{tabular}{|c|c|c|c|c|c|c|c|}
\hline \multicolumn{3}{|c|}{ City } & \multicolumn{5}{|c|}{ Region } \\
\hline \multirow{3}{*}{\multicolumn{3}{|c|}{ Formal Aspects }} & \multicolumn{5}{|c|}{ Substantial Aspects } \\
\hline & & & & \multirow{2}{*}{\multicolumn{2}{|c|}{$\begin{array}{c}2016 / 2018 \\
\text { Yes / No }\end{array}$}} & \multirow{2}{*}{\multicolumn{2}{|c|}{$\begin{array}{l}2013 / 2015 \\
\text { Yes / No }\end{array}$}} \\
\hline & & & & & & & \\
\hline \multirow{2}{*}{ Gender strategies } & 2016 / 2018 & $2013 / 2015$ & $\begin{array}{l}\text { Specific budget dedicated } \\
\text { to gender policies }\end{array}$ & & & & \\
\hline & Yes / No & Yes / No & Presence of indicators & \multicolumn{2}{|c|}{ Yes / No } & \multicolumn{2}{|c|}{ Yes / No } \\
\hline $\begin{array}{l}\text { Employment direct and } \\
\text { indirect discrimination }\end{array}$ & & & $\begin{array}{l}\text { Employment direct and } \\
\text { indirect discrimination }\end{array}$ & & & & \\
\hline $\begin{array}{l}\text { Reconciliation of family } \\
\text { and professional life }\end{array}$ & & & $\begin{array}{l}\text { Reconciliation of family } \\
\text { and professional life }\end{array}$ & & & & \\
\hline $\begin{array}{l}\text { Family equality between } \\
\text { men and women }\end{array}$ & & & $\begin{array}{l}\text { Family equality between } \\
\text { men and women }\end{array}$ & & & & \\
\hline $\begin{array}{l}\text { Women and political } \\
\text { decision-making }\end{array}$ & & & $\begin{array}{l}\text { Women and political } \\
\text { decision-making }\end{array}$ & & & & \\
\hline $\begin{array}{l}\text { Measures against gender } \\
\text { based violence and stalking }\end{array}$ & & & $\begin{array}{l}\text { Measures against gender } \\
\text { based violence and stalking }\end{array}$ & & & & \\
\hline Gender training & & & Gender training & & & & \\
\hline \multirow[t]{2}{*}{ Women and media } & & & Women and media & & & & \\
\hline & $\begin{array}{l}\text { Spread / } \\
\text { Not spread }\end{array}$ & $\begin{array}{l}\text { Spread I } \\
\text { Not spread }\end{array}$ & & & & & \\
\hline \multirow[t]{2}{*}{$\begin{array}{l}\text { Level of gender's strategies } \\
\text { wide-spreading }\end{array}$} & & & $\begin{array}{l}\text { Presence of a diagnosis } \\
\text { (contextualization) }\end{array}$ & \multicolumn{2}{|c|}{ Yes / No } & \multicolumn{2}{|c|}{ Yes / No } \\
\hline & Yes/ No & Yes/ No & $\begin{array}{l}\text { Employment direct and } \\
\text { indirect discrimination }\end{array}$ & & & & \\
\hline \multirow[t]{15}{*}{ Office/gender councilor } & & & $\begin{array}{l}\text { Reconciliation of family } \\
\text { and professional life }\end{array}$ & & & & \\
\hline & & & $\begin{array}{l}\text { Family equality between } \\
\text { men and women }\end{array}$ & & & & \\
\hline & & & $\begin{array}{l}\text { Women and political } \\
\text { decision-making }\end{array}$ & & & & \\
\hline & & & $\begin{array}{l}\text { Measures against gender } \\
\text { based violence and stalking }\end{array}$ & & & & \\
\hline & & & Gender training & & & & \\
\hline & & & Women and media & & & & \\
\hline & & & & \multicolumn{2}{|c|}{$2016 / 2018$} & \multicolumn{2}{|c|}{$2013 / 2015$} \\
\hline & & & Presence of a prognosis & 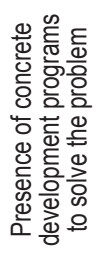 & 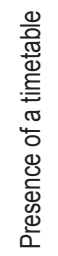 & 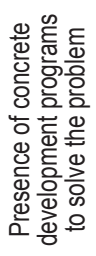 & 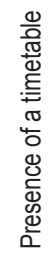 \\
\hline & & & $\begin{array}{l}\text { Employment direct and } \\
\text { indirect discrimination }\end{array}$ & & & & \\
\hline & & & $\begin{array}{l}\text { Reconciliation of family } \\
\text { and professional life }\end{array}$ & & & & \\
\hline & & & $\begin{array}{l}\text { Family equality between } \\
\text { men and women }\end{array}$ & & & & \\
\hline & & & $\begin{array}{l}\text { Women and political } \\
\text { decision-making }\end{array}$ & & & & \\
\hline & & & $\begin{array}{l}\text { Measures against gender } \\
\text { based violence and stalking }\end{array}$ & & & & \\
\hline & & & Gender training & & & & \\
\hline & & & Women and media & & & & \\
\hline
\end{tabular}

der inequalities. Another significant element is that municipalities with better performance in disseminating gender strategies also have a higher level of gender strategies wide-spreading; in other words, these local authorities have a more systematic 
diffusion of gender policies within each public policy issue, without relegating them mainly to social policies, alone.

Lastly, Table 4 shows the ranking reached in 2013/2015 and in 2016/2018 by Italian municipalities in developing each gender strategy, even if the absolute performance is, another time, weak considering the maximum score. The presence, or not, of the policy against 'direct and indirect employment discrimination' is very diffused as it underpins the increase in the number of women employed and, at the same time, the equality in employing conditions by the reconciliation of the family and professional life of gender targets.

Local authorities place increasing focus on 'gender training' and in developing 'measures against gender based violence and stalking'. Within gender training policies, some local authorities provide specific instructions designed to upgrade women's skills in lower and middle management positions, where women are often concentrated, within the municipality and also in other job positions (Maphunye, 2006; Siboni, Sangiorgi and Farneti, 2016).

Table 2: Results overview

\begin{tabular}{|c|c|c|c|c|c|c|c|c|c|c|c|c|c|c|}
\hline \multirow{3}{*}{ City } & \multicolumn{4}{|c|}{ Formal aspects } & \multicolumn{8}{|c|}{ Substantial aspects } & \multirow{2}{*}{\multicolumn{2}{|c|}{ Total }} \\
\hline & \multicolumn{2}{|c|}{ 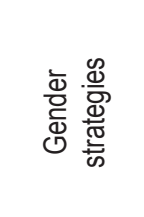 } & \multicolumn{2}{|c|}{ 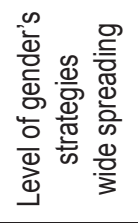 } & \multicolumn{2}{|c|}{ 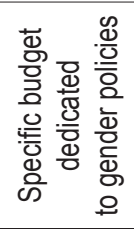 } & \multicolumn{2}{|c|}{ 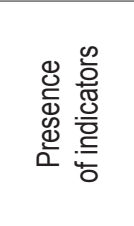 } & \multicolumn{2}{|c|}{ 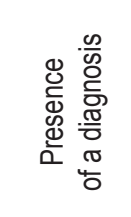 } & \multicolumn{2}{|c|}{ 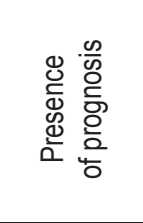 } & & \\
\hline & $\frac{\infty}{\delta}$ & $\frac{\stackrel{n}{\circ}}{\frac{N}{2}}$ & $\frac{\infty}{\stackrel{\infty}{\vdots}}$ & 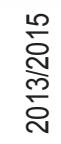 & $\frac{\infty}{\stackrel{\infty}{\vdots}}$ & $\frac{\stackrel{10}{\delta}}{\stackrel{N}{\infty}}$ & $\begin{array}{l}\frac{\infty}{\grave{n}} \\
\frac{\operatorname{d}}{\grave{0}}\end{array}$ & 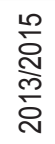 & $\frac{\infty}{\stackrel{N}{0}}$ & 尔 & $\begin{array}{l}\frac{\infty}{\delta} \\
\frac{N}{0} \\
\frac{N}{0}\end{array}$ & $\begin{array}{l}\frac{10}{2} \\
\frac{N}{0} \\
\stackrel{2}{0}\end{array}$ & $\frac{\infty}{\stackrel{\infty}{0}}$ & $\begin{array}{l}\frac{10}{0} \\
\frac{N}{0} \\
\frac{N}{\delta}\end{array}$ \\
\hline Ancona & 3 & 3 & 0 & 0 & 1 & 1 & 0 & 0 & 0 & 1 & 1.5 & 1.5 & 5.5 & 6.5 \\
\hline Aosta & 3 & 3 & 0 & 0 & 1 & 1 & 0 & 0 & 0 & 0 & 3 & 3 & 7 & 7 \\
\hline Bari & 4 & 4 & 0 & 0 & 0 & 0 & 0 & 0 & 2 & 1 & 0 & 0 & 6 & 5 \\
\hline Bologna & 7 & 7 & 1 & 1 & 1 & 1 & 2 & 1 & 7 & 7 & 3.5 & 3.5 & 21.5 & 20.5 \\
\hline Cagliari & 5 & 5 & 0 & 0 & 1 & 0 & 0 & 0 & 0 & 0 & 2 & 1 & 8 & 6 \\
\hline Campobasso & 2 & 3 & 0 & 0 & 0 & 0 & 0 & 0 & 0 & 0 & 0 & 0 & 2 & 3 \\
\hline Catanzaro & 4 & 3 & 0 & 0 & 0 & 0 & 0 & 0 & 0 & 0 & 0.5 & 1.5 & 4.5 & 4.5 \\
\hline Florence & 2 & 4 & 0 & 0 & 1 & 0 & 0 & 0 & 1 & 2 & 1.5 & 1 & 5.5 & 7 \\
\hline Genoa & 5 & 3 & 0 & 0 & 1 & 1 & 0 & 0 & 0 & 1 & 2 & 0.5 & 8 & 5.5 \\
\hline Milan & 5 & 5 & 0 & 0 & 1 & 1 & 0 & 0 & 5 & 5 & 2 & 2.5 & 13 & 13.5 \\
\hline Naples & 7 & 7 & 1 & 1 & 1 & 1 & 0 & 0 & 7 & 7 & 3.5 & 3.5 & 19.5 & 19.5 \\
\hline Palermo & 3 & 3 & 0 & 0 & 0 & 0 & 4 & 0 & 4 & 0 & 1.5 & 0 & 12.5 & 3 \\
\hline Perugia & 6 & 6 & 1 & 1 & 0 & 0 & 0 & 0 & 6 & 6 & 3 & 3 & 16 & 16 \\
\hline Potenza & 4 & 0 & 0 & 0 & 0 & 0 & 0 & 0 & 4 & 0 & 2 & 0 & 10 & 0 \\
\hline Rome & 3 & 6 & 0 & 0 & 0 & 0 & 0 & 0 & 2 & 4 & 1 & 2 & 6 & 12 \\
\hline Turin & 4 & 1 & 0 & 0 & 0 & 0 & 0 & 0 & 1 & 1 & 0.5 & 0 & 5.5 & 2 \\
\hline Trento & 4 & 2 & 1 & 1 & 1 & 0 & 1 & 1 & 3 & 2 & 1.5 & 1 & 11.5 & 7 \\
\hline Trieste & 6 & 3 & 0 & 0 & 1 & 1 & 0 & 0 & 1 & 0 & 1.5 & 1 & 9.5 & 5 \\
\hline Venice & 5 & 3 & 1 & 1 & 1 & 1 & 0 & 0 & 4 & 3 & 1.5 & 1.5 & 12.5 & 9.5 \\
\hline Total & 82 & 71 & 5 & 5 & 11 & 8 & 7 & 2 & 47 & 40 & 32 & 26.5 & 76 & 73 \\
\hline
\end{tabular}


Table 3: Municipalities ranking from 2013 to 2018

\begin{tabular}{|c|c|c|c|c|c|c|c|}
\hline \multirow[b]{2}{*}{ City ranking } & \multicolumn{2}{|c|}{ Formal aspects } & \multicolumn{4}{|c|}{ Substantial aspects } & \multirow[b]{2}{*}{$\begin{array}{c}\text { Ranking } \\
\text { (maximum score 60) }\end{array}$} \\
\hline & 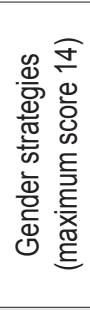 & 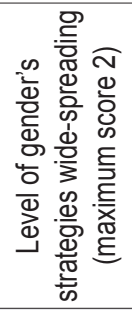 & 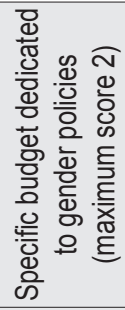 & 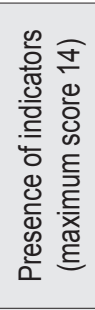 & 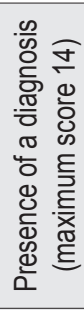 & 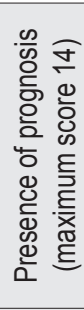 & \\
\hline 1. Bologna & 14 & 2 & 2 & 3 & 14 & 7 & 42 \\
\hline 2. Naples & 14 & 2 & 2 & 0 & 14 & 7 & 39 \\
\hline 3. Perugia & 12 & 2 & 0 & 0 & 12 & 6 & 32 \\
\hline 4. Milan & 10 & 0 & 2 & 0 & 10 & 4.5 & 26.5 \\
\hline 5. Venice & 8 & 2 & 2 & 0 & 7 & 3 & 22 \\
\hline 6. Trento & 6 & 2 & 1 & 2 & 5 & 2.5 & 18.5 \\
\hline 7. Rome & 9 & 0 & 0 & 0 & 6 & 3 & 18 \\
\hline 8. Palermo & 6 & 0 & 0 & 4 & 4 & 1.5 & 15.5 \\
\hline 9. Trieste & 9 & 0 & 2 & 0 & 1 & 2.5 & 14.5 \\
\hline 10. Aosta & 6 & 0 & 2 & 0 & 0 & 6 & 14 \\
\hline 10. Cagliari & 10 & 0 & 1 & 0 & 0 & 3 & 14 \\
\hline 11. Genoa & 8 & 0 & 2 & 0 & 1 & 2.5 & 13.5 \\
\hline 12. Florence & 6 & 0 & 1 & 0 & 3 & 2.5 & 12.5 \\
\hline 13. Ancona & 6 & 0 & 2 & 0 & 1 & 3 & 12 \\
\hline 14. Bari & 8 & 0 & 0 & 0 & 3 & 0 & 11 \\
\hline 15. Potenza & 4 & 0 & 0 & 0 & 4 & 2 & 10 \\
\hline 16. Catanzaro & 7 & 0 & 0 & 0 & 0 & 2 & 9 \\
\hline 17. Turin & 5 & 0 & 0 & 0 & 2 & 0.5 & 7.5 \\
\hline 18. Campobasso & 5 & 0 & 0 & 0 & 0 & 0 & 5 \\
\hline
\end{tabular}

Table 4: Strategies' ranking 2013/2015 and 2016/2018

\begin{tabular}{|c|c|c|c|c|c|c|c|c|c|c|}
\hline \multirow[b]{2}{*}{ Strategies } & \multicolumn{2}{|c|}{$\begin{array}{c}\text { Gender } \\
\text { strategies }\end{array}$} & \multicolumn{2}{|c|}{$\begin{array}{c}\text { Presence } \\
\text { of indicators }\end{array}$} & \multicolumn{2}{|c|}{$\begin{array}{c}\text { Presence } \\
\text { of a diagnosis }\end{array}$} & \multicolumn{2}{|c|}{$\begin{array}{c}\text { Presence } \\
\text { of prognosis }\end{array}$} & \multicolumn{2}{|c|}{ Ranking } \\
\hline & 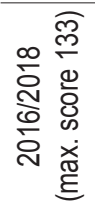 & 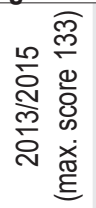 & 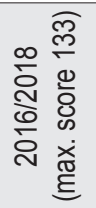 & 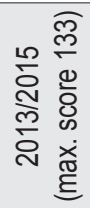 & 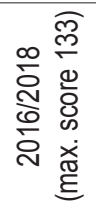 & 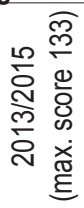 & 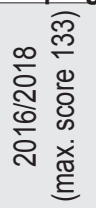 & 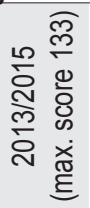 & 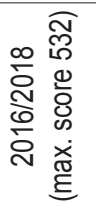 & 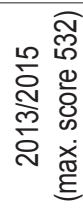 \\
\hline $\begin{array}{l}\text { Reconciliation of family } \\
\text { and professional life }\end{array}$ & 18 & 15 & 1 & 1 & 9 & 6 & 6.5 & 4.5 & 34.5 & 26.5 \\
\hline $\begin{array}{l}\text { Direct and indirect employ- } \\
\text { ment discrimination }\end{array}$ & 15 & 15 & 0 & 0 & 11 & 9 & 6.5 & 4.5 & 32.5 & 28.5 \\
\hline Gender training & 16 & 13 & 0 & 0 & 7 & 8 & 6.5 & 5 & 29.5 & 26 \\
\hline $\begin{array}{l}\text { Measures against gender } \\
\text { based violence and stalking }\end{array}$ & 15 & 11 & 1 & 1 & 7 & 5 & 5 & 3 & 28 & 20 \\
\hline $\begin{array}{l}\text { Women and political } \\
\text { decision-making }\end{array}$ & 7 & 8 & 0 & 0 & 6 & 7 & 2.5 & 3 & 15.5 & 18 \\
\hline Women and media & 7 & 5 & 1 & 0 & 4 & 4 & 3 & 2.5 & 15 & 11.5 \\
\hline $\begin{array}{l}\text { Family equality between } \\
\text { men and women }\end{array}$ & 4 & 3 & 0 & 0 & 3 & 2 & 1.5 & 1 & 8.5 & 6 \\
\hline Total & 82 & 70 & 3 & 2 & 47 & 41 & 31.5 & 23.5 & 163.5 & 136.5 \\
\hline
\end{tabular}


If we consider that gender issues' priority must be identified, selected and included in effective development programs, content analysis results show that GM strategies have often been arbitrarily identified without a direct connection within the local framework. In other words, municipalities frequently pick out gender strategies not based on a specific diagnosis (Table 4). Consequently, they do not declare the performance target they aim to achieve. The presence of a correct diagnosis is the cornerstone of GM, and its absence is a weak link in the overall program planning process (World Bank, 2012). The diagnosis should encompass the current policy environment, the political climate, the organizational structures and cultures in which the municipality's strategy is situated, and it has to be built on what has been learned from the well-evaluated experiences from previous programs. Access to national data, such as gender statistics and operations research, is fundamental for prognosis analysis, as well as qualitative data generated through local policy and participation assessments (Moser, 2007). A deep prognosis analysis is the basis for monitoring the key trends in local implementation on gender equality, mapping out key stakeholder' positions and needs, learning from past experience, anticipating risks and benefits linked with GM strategies.

There is no connection between GM strategies and targeted intervention, as these are not frequently explicit. While Italian local authorities are able to issue a detailed program for gender equality by identifying priority issues, target groups and coverage, at the same time they fail in identifying indicators, intervention modalities, measuring and monitoring results (Table 3). Without monitoring and evaluation activities, municipalities are unable to report and, above all, to readjust strategies in response to results.

Research results show that strategies linked to GM are not systematic and are considered a one-time activity, rather than a crucial step to provide information to develop and adjust gender equality programming. The findings of GM should be used to actually shape or adjust the design and implementation of strategies, programs and projects and consequently, to feed the policy-making and programming cycle. Research results suggest that focus should also be on the extent to which GM policies and initiatives are translating into meaningful change within the local territory (Connell, 2006).

Another issue highlighted by this study concerns financial resources to implement goals and policy commitments to gender equality objectives: few municipalities give information on resources allocated within the budget and none regarding return on gender investments (Table 3).

In addition, the results concerning the presence of specific indicators reveal several problems: indicators are rare and very general (Table 3). Instead of fixing specific, measurable, accurate and time-bound indicators, the few measures are referred only to non-objective quantities or to time-tabled targets. No municipalities disaggregated indicators on different groups (e.g., by sex, ethnic group, age, disabilities, health status, income, sexual orientation, gender identity, etc.). A balanced mix of qualita- 
tive and quantitative indicators is essential to generate more and diverse information. Moreover, a stronger accountability on mandatory documents - such as DUP and PAP - could add credibility to the local GM policies. The Italian GM approach needs to be accompanied by concrete programs with practical steps to enhance gender equality; further, the impact of these policies also needs to be measured, monitored and evaluated systematically.

\section{Conclusions}

The article's aim is to contribute to the on-going debate in the literature and to the policy decisions about the local policies for disseminating gender equality. Whilst existing literature and studies tend to focus on EU policies or on specific state initiatives, this article examines local policies for gender equality and, consequently, highlights GM at local level. These findings have implications for public administrations and policy makers, as they highlight several different action lines to disseminate gender equality.

Considering the first research question, the conclusion of the analysis is that the local authorities are demonstrating more commitment with policies linked to employment issues. Moreover, data analysis shows uniformity in engaging with gender equality policies: everybody agrees on the necessity to coordinate governance and public strategies in order to achieve gender equality. This is a fundamental issue: policy benefits to assure equal opportunities are strictly linked to efforts in knowing the public's needs according to gender diversities.

The major dilemma facing most municipalities is not whether to deal with gender inequalities, but how. Research results reveal a huge quantity of affirmative action but this cannot be automatically converted into effective strategies. A lack of initial analysis was noted, plus a poor capacity to discover the inequities of the territory, while a steady quantity of statistic and social data is presented in the documents. Few municipalities are able to contextualize and to quantify this information within the gender inequality panorama.

Research results highlight Italian municipalities' significant commitment to spreading GM policies, not only dedicated to women but also to a more inclusive concept of 'gender', including disabled, youth, elderly and sometimes, transgender people. Policies are more extensive and transversal as they involve different offices and services. However, they lack clear, unambiguous guidelines for implementation and this undermines the very efforts aimed at spreading gender equality.

Another critical element concerns the differences within municipalities that apply GM strategies in different ways and display different engagements with financial, human and material resources. This may increase differences and, consequently, inequalities within the Italian regional panorama (Gori, Fissi and Manetti, 2012).

The number of local policies issued with inbuilt gender equality is increasing, yet many of the non-discrimination policies are impotent, as we have no evidence concerning their real impact. In other words, we can conclude that Italian local authorities are gender sensitive but not gender effective. 
If we consider the second research question, we argue that, unfortunately, Italian policies for gender equality are not target-driven. Local authorities widespread a wide range of gender policies without defining an adequate tool. Often, there is a feeling that gender policies have been issued to promote general principles, without focusing on concrete actions or, worse, just for symbolic reasons.

Without measuring tools, it is impossible to evaluate the impact of gender policies. Italian local authorities are involved in disseminating gender equality but only a minority is able to explain the effects of their policies. Policies alone do not achieve desired outcomes: they need to be supported by implementation strategies, action plans, capacity building and dedicated resources, as well as monitoring and accountability mechanisms. These elements are the basis for gender equality. The implementation of gender mainstreaming's strategies need re-clarification and revitalization by focusing more on performance and results.

Overall, to effectively achieve policy and program results for women, men, boys and girls, policy makers need to develop measuring tools and incorporate both multiple-level and multiple-track responses within any stakeholder needs. From this point of view, research results show that the Italian local authorities' approach is not 'pervasive', as it is unable to find out systematic and positive actions. There is an ongoing and urgent need for developed tools and indicators for monitoring and evaluating the outcome of gender strategies within national and local programs. Policy makers need to reflect on the possibility to develop a clear frame concerning strategies, resources, measuring and impact indicators in order to build real 'gender effective policies'.

This study has several limitations. The first one is concerned with the analyzed municipalities, as they represent only a part of the whole Italian local authorities' population. Further research development needs to improve results by enlarging the studied population and by enriching results with interviews to better understand the commitment of local public actors in achieving gender equality. The second boundary is that the gender equality policy's success depends not only on the tools used to measure it but also on individual target characteristics, such as race and education, etc.

\section{Authors' contribution}

A draft version of this paper was previously presented by the authors during the $21^{\text {st }}$ International Research Society on Public Management Conference held in Budapest, April 19-21, 2017. Although this work represents a joint study by the authors, sections 1 and 6 can be attributed to Elena Gori, 2 and 3 to Alberto Romolini, 4 and 5 to Silvia Fissi.

\section{References:}

1. Acker, J., 'Gendered Institutions: From Sex Roles to Gendered Institutions', 1992, Contemporary Sociology, vol. 21, no. 5, pp. 565-569.

2. Bendl, R. and Schmidt, A., 'Gender Mainstreaming: An Assessment of Its Conceptual Value for Gender Equality', 2013, Gender, Work \& Organization, vol. 20, no. 4, pp. 364-381. 
3. Budlender, D. and Hewitt, G., Engendering Budgets: A Practitioners' Guide to Understanding and Implementing Gender-responsive Budgets, London: The Commonwealth Secretariat, 2003.

4. Çağatay, N., 'Gender Budgets and Beyond: Feminist Fiscal Policy in the Context of Globalization', 2003, Gender and Development, vol. 11, no. 1, pp. 15-24.

5. Connell, R.W. and Messerschmidt, J.W., 'Hegemonic Masculinity: Rethinking the Concept', 2005, Gender \& Society, vol. 19, no. 3, pp. 29-50.

6. Connell, R.W., 'Glass Ceilings or Gendered Institutions? Mapping the Gender Regimes of Public Sector Worksites', 2006, Public Administration Review, vol. 66, no. 6, pp. 837-849.

7. Daly, M., 'Gender Mainstreaming in Theory and Practice', 2005, Social Politics: International Studies in Gender, State \& Society, vol. 12, no. 3, pp. 433-450.

8. David, M. and Guerrina, R., 'Gender and European External Relations: Dominant Discourses and Unintended Consequences of Gender Mainstreaming', 2013, Women's Studies International Forum, vol. 39, July-August, pp. 53-52.

9. Davies, A. and Thomas, R., 'Gendering and Gender in Public Service Organizations. Changing Professional Identities under New Public Management', 2002, Public Management Review, vol. 4, no. 4, pp. 461-484.

10. Davies, A. and Thomas, R., 'Researching Public Sector Change. The Argument for a Gender-Inclusive Framework', 2000, Public Management Review, vol. 2, no. 4, pp. 547-554.

11. Directive Prodi-Finocchiaro (Italian Prime Minister Decree, 27 March 1997), 'Azioni volte a promuovere l'attribuzione di poteri e responsabilità alle donne, a riconoscere e garantire libertà di scelte e qualità sociale a donne e uomini'.

12. European Commission, EU Plan of Action on Gender Equality and Women's Empowerment in Development, SEC(2010)265 final, 2010.

13. European Commission, The Impact of the Economic Crisis on the Situation of Women and Men and on Gender Equality Policies. Synthesis Report, Luxembourg: Directorate General for Justice, 2013.

14. European Institute for Gender Equality (EIGE), EIGE in Brief, Luxembourg: Publications Office of the European Union, 2015a.

15. European Institute for Gender Equality (EIGE), What is Gender Mainstreaming, Luxembourg, Publications Office of the European Union, 2015b.

16. European Institute for Gender Equality (EIGE), Strategic Engagement for Gender Equality 2016-2019, Luxembourg: Publications Office of the European Union, 2015c.

17. European Institute for Gender Equality (EIGE), Gender Equality Index 2015, Luxembourg: Publications Office of the European Union, 2015d.

18. Galizzi, G. and Siboni, B., 'Positive Action Plans in Italian Universities: Does Gender Really Matter?', 2016, Meditari Accountancy Research, 2016, vol. 24, no. 2, pp. 246-268.

19. Gori, E., Fissi, S. and Manetti, G., 'The Performance Nursery School in Italian Municipalities', 2012, International Journal of Public Administration, vol. 35, no. 14, pp. 959-975.

20. Guthrie, J. and Abeysekera, J., 'Content Analysis of Social, Environmental Reporting: What Is New?', 2006, Journal of Human Resource Costing \& Accounting, vol. 10, no. 2, pp. 114-126.

21. Kangasniemi, M. and Kauhanen, A., 'Performance-related Pay and Gender Wage Differences', 2013, Applied Economics, vol. 45, no. 36, pp. 5131-5143. 
22. Law no. 151 from 19 May 1975, 'Riforma del diritto di famiglia'.

23. Law no. 53 from 8 May 2000, 'Disposizioni per il sostegno della maternità e della paternità, per il diritto alla cura e alla formazione e per il coordinamento dei tempi delle città'.

24. Lehman, C., 'We've Come a Long Way! Maybe! Re-imagining Gender and Accounting', 2012, Accounting, Auditing \& Accountability Journal, vol. 25, no. 2, pp. 256-294.

25. Lombardo, E. and Del Giorgio, E., 'EU Antidiscrimination Policy and Its Unintended Domestic Consequences: The Institutionalization of Multiple Equalities in Italy', 2013, Women's Studies International Forum, vol. 39, July-August, pp. 12-21.

26. Lombardo, E. and Meier, P., 'Framing Gender Equality in the European Union Political Discourse', 2008, Social Politics: International Studies in Gender, State and Society, vol. 15 , no. 1, pp. 101-129.

27. Luckerath-Rovers, M., 'Women on Boards and Firm Performance', 2013, Journal of Management and Governance, vol. 17, no. 2, pp. 491-509.

28. Maphunye, K., 'Towards Redressing Historical Inequities? Gender Balancing in the South African Civil Service', 2006, Public Management Review, vol. 8, no. 2, pp. 297-311.

29. Martini, M., 'Il bilancio di genere nella prassi italiana. Indagine empirica sui comportamenti degli enti locali', 2011, Rivista Italiana di Ragioneria e di Economia Aziendale, vol. 111, no. 3/4, pp. 191-203.

30. Mastracci, S. and Bowman, L., 'Public Agencies, Gendered Organizations. The Future of Gender Studies in Public Management', 2015, Public Management Review, vol. 17, no. 6, pp. 857-875.

31. Moser, A., 'Gender and Indicators: Overview Report', Institute of Development Studies, 2007, [Online] available at http://www.bridge.ids.ac.uk/sites/bridge.ids.ac.uk/files/ reports/IndicatorsORfinal.pdf, accessed on January 2017.

32. Moser, C. and Moser, A., 'Gender Mainstreaming since Beijing: A Review of Success and Limitations in International Institutions', 2005, Gender and Development, vol. 13, no. 2, pp. 11-22.

33. Nielsen, S. and Huse, M., 'Women Directors' Contribution to Board Decision-making and Strategic Involvement: The Role of Equality Perception', 2010, European Management Review, vol. 7, no. 1, pp. 16-29.

34. Parker, L.D., 'Social and Environmental Accountability Research: A View from the Commentary Box', 2005, Accounting, Auditing \& Accountability Journal, vol. 18, no. 6, pp. 842-860.

35. Pollack, A. and Hafner-Burton, M., 'Mainstreaming Gender in the European Union', 2000, Journal of European Public Policy, vol. 7, no. 3, pp. 432-456.

36. Pulejo, L., 'Gender Mainstreaming e Politiche Pubbliche', in Borowiecki, R. and Jaki, A. (eds.), Challenges and Barriers of the 21 $1^{\text {st }}$ Century Economy. Economic, Legal, Social and Ecological Aspects, Department of Economics and Organization of Enterprises, Cracow, Poland: Cracow University of Economics, 2009, pp. 91-104.

37. Pulejo, L., 'Il profilo di genere nella programmazione delle aziende pubbliche territoriali', 2011a, Management Control, vol. 2, pp. 59-83.

38. Pulejo, L., La gender equality nell'economia dell'azienda. Strategie e strumenti di mainstreaming di genere per lo sviluppo sostenibile, Milan: FrancoAngeli, $2011 \mathrm{~b}$. 
39. Riccucci, N.M., 'The Pursuit of Social Equity in the Federal Government: A Road Less Travelled?', 2009, Public Administration Review, vol. 69, no. 3, pp. 373-382.

40. Rosselli, A., The Policy on Gender Equality in Italy, Brussels: European Parliament, 2014, [Online] available at http://www.europarl.europa.eu/studies, accessed on 12 January 2017.

41. Sellers, M.D., 'Discrimination and the Transgender Population: Analysis of the Functionality of Local Government Policies that Protect Gender Identity', 2014, Administration $\mathcal{E}$ Society, vol. 46, no. 1, pp. 70-86.

42. Siboni, B., Sangiorgi, D. and Farneti, F., 'Gender (in) Accounting: Insights, Gaps and an Agenda for Future Research', 2016, Meditari Accountancy Research, vol. 24, no. 2, pp. 158-168.

43. Tiessen, R., Everywhere/Nowhere: Gender Mainstreaming in Development Agencies, Bloomfield: Kumarian Press, 2007.

44. United Nations, Gender Mainstreaming in Development Programming, New York: United Nations Women, 2014a.

45. United Nations, Gender Equality in Public Administration, New York: United Nations Development Programme, 2014b.

46. United Nations, Gender Mainstreaming. An Overview, New York: Office of Special Adviser on Gender Issues and Advancement of Women, 2002.

47. Verloo, M., 'Mainstreaming Gender Equality in Europe: A Critical Frame Analysis Approach', 2005, The Greek Review of Social Research, vol. 117, pp. 11-34.

48. Walby, S., Gender Mainstreaming: Productive Tensions in Theory and Practice, in Social Politics, Oxford, England: Oxford University Press, 2003.

49. Woodward, A., 'Too Late for Gender Mainstreaming? Taking Stock in Brussels', 2008, Journal of European Social Policy, vol. 18, no. 3, pp. 289-302.

50. World Bank, World Development Report 2012: Gender Equality and Development, Washington, DC: World Bank, 2012. 